\title{
PENGUJIAN PENGHAMBATAN ENZIM TIROSINASE PADA FORMULASI MASKER PENCERAH WAJAH DARI KOMBINASI KEFIR SUSU SAPI DAN RUMPUT LAUT (Eucheuma cottonii)
}

\author{
Fenti Fatmawati ${ }^{1}$, Garnadi Jafar ${ }^{1}$, Ria Riantini ${ }^{1}$ \\ ${ }^{1}$ Fakultas Farmasi Bhakti Kencana University \\ fenti.fatmawati@bku.ac.id
}

\begin{tabular}{l}
\hline $\begin{array}{l}\text { Artikel Info } \\
\text { Diterima } \\
\text { tanggal } \\
11.03 .2020 \\
\text { Disetujui } \\
\text { publikasi } \\
\text { tanggal } \\
\text { 30.04.2020 } \\
\text { Kata kunci : } \\
\text { IC50, kefir, } \\
\text { rumput laut, } \\
\text { tirosinase }\end{array}$ \\
\hline
\end{tabular}

\begin{abstract}
ABSTRAK
Kefir telah dikenal memiliki banyak sekali khasiat diantaranya untuk kulit. Rumput laut juga dikenal memiliki kandungan mineral yang berkhasiat untuk kecantikan kulit. Tujuan penelitian ini adalah mendapatkan formulasi masker pencerah wajah dari kombinasi kefir dan rumput laut dan mengetahui nilai penghambatan enzim tirosinasenya. Dari hasil evaluasi sediaan (Uji Homogenitas, Uji pH, Uji viskositas, Uji Iritasi, Uji tipe krim) pada formulasi masker didapatkan bahwa formula 3 (F3) adalah formula yang paling baik. Dilakukan uji penghambatan tirosinase dan didapatkan nilai IC50 sebesar $0,26 \%$ yang nilainya lebih rendah dari pada kontrol dimana nilai IC50 dari kontrol yaitu 1,24\%. Dapat disimpulkan bahwa hasil uji penghambatan tirosinase sampel memiliki aktivitas sebagai inhibitor tirosinase yang baik.
\end{abstract}

\begin{abstract}
Kefir has been known to have many properties for the skin. Seaweed is also known to have a useful mineral for skin beauty. The purpose of this study was to obtain a face lightening mask formulation from a combination of kefir and seaweed and determine the inhibitory value of the tyrosinase enzyme From the evaluation results of preparations (Homogeneity Test, pH Test, Viscosity Test, Irritation Test, Cream type Test) on the mask formulation it was found that formula 3 (F3) is the best formula. Tyrosinase inhibition test was performed and the IC50 value was $0.26 \%$ which was lower than the control where IC50 value of the control was $1.24 \%$. It can be concluded that the results of sample tyrosinase inhibition test have activity as a good tyrosinase inhibitor.
\end{abstract}

\section{PENDAHULUAN}

Kosmetik merupakan bahan yang di aplikasikan secara topikal yang digunakan untuk menghilangkan kotoran kulit, mempertahankan komposisi cairan kulit, melindungi kulit dari paparan sinar ultraviolet, memperlambat timbulnya kerutan, memperbaiki penampilan, dan meningkatkan rasa percaya diri (Solihin dkk., 2012). Pembuatan kosmetik dari bahan alami lebih baik dari pada bahan sintesis maka dibuat kosmetik dari bahan baku susu. Kefir merupakan

doi: http://dx.doi.org/10.23960/aec.v5.i1.2020.p42-52

Anal.Environ.Chem. 
produk fermentasi susu yang diproduksi oleh mikroorganisme yang disajikan dari biji kefir pada susu. Dalam biji kefir, bakteri asam laktat dan ragi tertanam dalam matriks polisakarida berlendir bernama kefiran, diduga diproduksi oleh lactobacilli di biji-bijian). Di Indonesia, kefir mulai digemari oleh masyarakat sebagai makanan fungsional, Secara empiris kefir digunakan untuk mengobati jerawat dengan cara membasuh muka menggunakan air tersebut atau dengan menggerus butir kefir dan membalurkannya ke muka sebagai masker (Otles dan Cagindi, 2003 ; Michael et al.,2014).

Rumput laut adalah tanaman yang liar dan tumbuh dilautan yang merupakan kategori algae atau ganggang. Kandungan rumput laut itu sendiri mengandung nutrisi alami seperti vitamin A, B1, B2, B12, C,D, E, F, K, mineral dan asam lemak yang baik bagi tubuh. Manfaat Rumput laut untuk kecantikan karena mengandung mineral yang sangat kaya dan dibutuhkan oleh kulit seperti vitamin B kompleks, vitamin C, magnesium, dan berbagai mineral lainnya yang membantu metabolisme sel kulit. Kandungan mineral yang ada pada rumput laut dapat melancarkan metabolisme aliran darah dan mengeluarkan racun yang ada pada tubuh (Wibowo, Fitriyani., 2012). Tujuan penelitian ini adalah adalah mendapatkan formulasi masker pencerah wajah dari kombinasi kefir dan rumput laut dan mengetahui nilai penghambatan enzim tirosinasenya.

\section{METODE}

\section{Alat dan Bahan}

Alat yang digunakan yaitu timbangan analitik (Mettler toledo), wadah kaca besar, pot salep kaca 100gram, vial 10ml dan 20ml, hot plate, batang pengaduk, spatel, objek glass, $\mathrm{pH}$ meter (Mettler toledo), thermometer, beker glass 600 $\mathrm{ml}$ dan 1000ml (Duran), blender (Miyako), gelas ukur 10ml (Iwaki), 50ml dan 100ml (Iwaki), viskometer Brookfield (DV-II+ Pro), alat Homogenizer (Ika rw 20), ELISA reader (Themor) panjang gelombang 450nm, orbital shaker (Ika ks 4000i), Rotary evaporator, Autoclave.

Bahan yang digunakan yaitu kefir susu sapi, rumput laut Eucheuma cotonii, aquadest, aquabides, dm dm hydantoin, PVA, setil alkohol, tween 80, TEA, buffer fosfat pH 6,0, $\mathrm{HCl} 3 \mathrm{M}$, L-DOPA $10 \mathrm{mM}$, asam kojat $10 \%$ dan enzim tirosinase $150 \mathrm{U} / \mathrm{ml}$.

doi: http://dx.doi.org/10.23960/aec.v5.i1.2020.p42-52

Anal.Environ.Chem. 


\section{Prosedur}

\section{- Determinasi Rumput Laut}

Determinasi rumput laut (Eucheuma cottonii) dilakukan di Universitas Padjajaran.

\section{- Pembuatan Kefir Susu sapi}

Susu sapi yang telah dipasteurisasi disiapkan sebanyak 1L. Sebanyak 50 gram grain kefir dimasukan ke dalam wadah lalu diaduk hingga merata, diinkubasi pada suhu kamar $\left(37^{\circ} \mathrm{C}\right)$ selama $24 \mathrm{jam}$ sehingga diperoleh kefir segar. Pada proses ini terjadi pemisahan antara kefir dan whey. Dilakukan pemisahan antara kefir dan whey dengan cara disaring menggunakan kain steril. Kefir selanjutnya digunakan sebagai masker.

\section{- Ekstraksi Rumput laut}

Metode Ekstraksi dengan menggunakan pelarut metanol. Ekstraksi dilakukan sebanyak 3 kali pengulangan. Sampel Euhceuma cottonii dihaluskan dengan blender ditimbang sebanyak 300 gram kemudian dimaserasi menggunakan pelarut metanol sebanyak $600 \mathrm{~mL}$. Proses maserasi dilakukan 1x24jam menggunakan Orbital shaker 180rpm dengan suhu $24^{\circ} \mathrm{C}$. Hasil maserasi disaring menggunakan kertas saring sehingga diperoleh filtrat dan residu. Filtrat kemudian dievaporasi hingga pelarut terpisah dengan ekstrak menggunakan rotari vacuum evaporator pada suhu $40^{\circ} \mathrm{C}$ hingga diperoleh ekstrak kasar.

\section{Pembuatan Masker}

Komposisi bahan masker wajah kefir susu sapi dan rumput Laut dapat dilihat seperti pada Tabel 1.

Tabel 1. Variasi formulasi yang dibuat sediaan

\begin{tabular}{llllll}
\hline \multirow{2}{*}{\multicolumn{1}{c}{ Bahan }} & \multicolumn{5}{c}{ Formula \% b/v } \\
\cline { 2 - 6 } & \multicolumn{1}{c}{ F1 } & F2 & F3 & F4 & \multicolumn{1}{c}{ F5 } \\
\hline Kefir & 44,25 & 33,18 & 22,12 & 11,06 & 0 \\
Rumput Laut & 0 & 11,06 & 22,12 & 33,18 & 44,25 \\
Dm Dm Hydantoin & 1 & 1 & 1 & 1 & 1 \\
Cetil alkohol & 1 & 1 & 1 & 1 & 1 \\
PVA & 7,5 & 7,5 & 7,5 & 7,5 & 7,5 \\
Tween80 & 2 & 2 & 2 & 2 & 2 \\
TEA & 0.1 & 0.1 & 0.1 & 0.1 & 0.1 \\
Aquabides & 44,25 & 44,25 & 44,25 & 44,25 & 44,25 \\
\hline
\end{tabular}

doi: http://dx.doi.org/10.23960/aec.v5.i1.2020.p42-52 
Pencampuran bahan dilakukan dengan menimbang bahan-bahan yang digunakan. PVA dilarutkan terlebih dahulu menggunakan aquabides dengan suhu $70^{\circ} \mathrm{C}$ yang ditambahkan sedikit demi sedikit sampai larut sempurna. Cetil alkohol dilelehkan dalam cawan lalu dimasukkan ke dalam beaker glass yang terdapat PVA sambil diaduk sampai homogen. Kefir dan rumput laut dimasukan sambil tetap diaduk. Tween80 dimasukan dan diaduk sampai homogen. TEA dimasukan aduk sampai homogen. Dm Dm Hydantoin dan aquabides dimasukan lalu aduk sampai homogen dengan menggunakan alat Homogenizer dengan kecepatan 3000rpm. Pengadukan dihentikan ketika sudah terbentuk tekstur yang halus ( Wahyuni dkk., 2016 )

\section{- Uji Evaluasi Masker}

\section{Uji homogenitas}

Pengujian dilakukan 1 kali pada hari ke-0 (Wahyuni dkk., 2016).

\section{Uji pH}

pH sediaan yang baik harus berada di kisaran 4 -5,5. Pengujian dilakukan pada hari ke 0 , 7, 14, 21 dan 28 (Rahmawati dkk., 2010 ; Wibowo. SA., 2017).

\section{Uji viskositas}

Dilakukan uji agar diketahui kekentalan dari sediaan. Viskositas krim diukur dengan menggunakan alat Viscometer Brook Field. Sediaan sebanyak 50 gram dimasukan ke dalam beaker glass. Spindle di set no 7 dengan kecepatan $20 \mathrm{rpm}$. Pengujian dilakukan pada hari ke $0,7,14,21$ dan 28. Nilai viskositas yang baik untuk sediaan krim derada di kisaran 2000 sampai 50.000Cps (Rahmawati dkk., 2010 ; Wibowo. SA., 2017; Mektildis.,2016).

\section{Uji iritasi}

Penggunaan masker wajah diuji coba terlebih dahulu pada punggung tangan dan dilakukan pada 10 orang responden. Masker dioleskan, ditunggu selama 15-30 menit lalu dilihat hasilnya, apakah aman untuk digunakan atau tidak. Apabila terdapat ruam atau gatal maka sediaan tidak aman untuk digunakan. Pengujian diakukan pada hari ke 0,7, 14, 21 dan 28 ( Anindita.AH dan AF.Swaidatul dkk., 2016).

\section{Uji Tipe Krim}

doi: http://dx.doi.org/10.23960/aec.v5.i1.2020.p42-52 
Uji tipe krim digunakan untuk mengetahui masker krim termasuk kedalam tipe krim minyak dalam air atau air dalam minyak. (Depkes RI, 1985 ; Erawati dkk 2015).

\section{Uji kecerahan dengan Pengujian Penghambatan Enzim}

Asam kojat digunakan sebagai kontrol. Persentase penghambatan tirosinase dihitung menggunakan rumus:

(Serapan A-B) - (Serapan C-D) X 100\%

(Serapan A-B)

\section{Pengukuran aktivitas Inhibisi tirosinase (IC50) dari sampel dan kontrol}

Adapun komposisi untuk pengujian IC50 ini seperti pada Tabel 2.

Tabel 2. Komposisi pengujian IC50

\begin{tabular}{lllll}
\hline & Tube A & Tube B & Tube C & Tube D \\
\hline Buffer & $80 \mu \mathrm{l}$ & $80 \mu \mathrm{l}$ & $80 \mu \mathrm{l}$ & $80 \mu \mathrm{l}$ \\
L-Dopa & $40 \mu \mathrm{l}$ & $40 \mu \mathrm{l}$ & $40 \mu \mathrm{l}$ & $40 \mu \mathrm{l}$ \\
Sampel / & - & - & $40 \mu \mathrm{l}$ & $40 \mu \mathrm{l}$ \\
Kontrol & & & & \\
Enzim & $40 \mu \mathrm{l}$ & - & $40 \mu \mathrm{l}$ & - \\
Tirosinase & & & & \\
\hline
\end{tabular}

\section{HASIL DAN PEMBAHASAN}

Dalam penelitian ini dilakukan beberapa tahapan mulai dari persiapan bahan dan pembuatan bahan utama yaitu kefir susu sapi dan rumput laut yang selanjutnya dibuat sediaan Masker wajah.

\section{- Determinasi Tanaman Rumput Laut (Euceuma cottonii)}

Berdasarkan hasil Determinasi menunjukan bahwa tanaman yang dipakai pada penelitian adalah rumput laut dari spesies Euceuma cottonii.

doi: http://dx.doi.org/10.23960/aec.v5.i1.2020.p42-52 


\section{- Pembuatan masker}

Sediaan masker dapat dilihat pada Gambar 1.

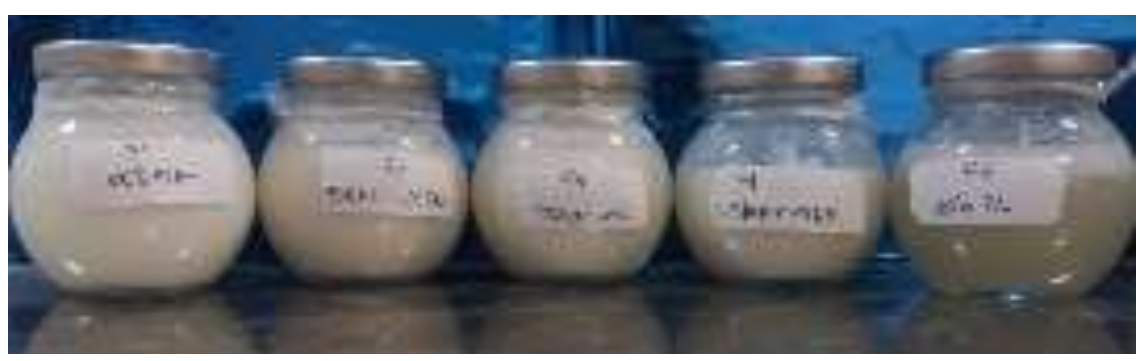

Gambar 1. Sediaan Masker

\section{- Uji Evaluasi Masker}

\section{Uji Homogenitas}

Uji dilakukan pada semus formula yaitu F1,F2,F3,F4 dan F5 adapun hasil dari pengujian terdapat pada Gambar 2.

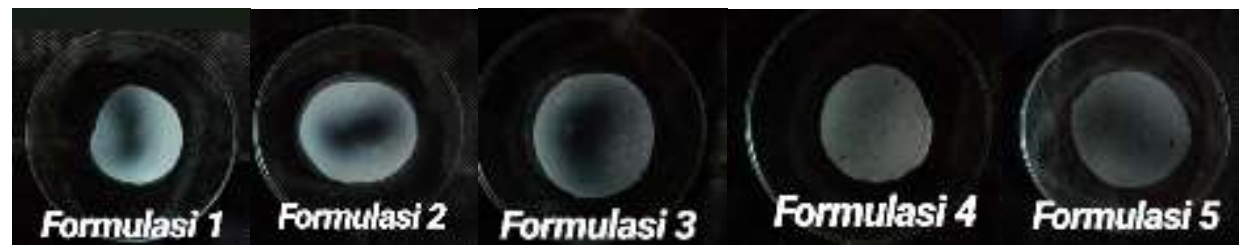

Gambar 2. Pengujian Homogenitas

Homogenitas dari sediaan masker krim yang telah di uji menggunakan kaca objek menunjukan bahwa pada F1,F2,F3 dan F4 sediaan tidak homogen karena kefir yang digunakan memiliki tekstur lembut dan terdapat butiran-butiran kecil, sementara pada F5 dengan 100\% rumput laut didapatkan sediaan yang homogen.

\section{2. $\quad$ Uji pH}

Pengujian $\mathrm{pH}$ sediaan didapatkan data yang terdapat pada tabel 3 .

doi: http://dx.doi.org/10.23960/aec.v5.i1.2020.p42-52 
Tabel 3. Pengujian $\mathrm{pH}$

\begin{tabular}{crrrrr}
\hline & \multicolumn{5}{c}{ Waktu Pengujian } \\
\cline { 2 - 6 } Formulasi & Hari & Hari & Hari & Hari & Hari \\
& ke- 0 & ke-7 & ke-14 & ke-21 & ke-28 \\
\hline F1 & 4,54 & 4,60 & 4,66 & 4,69 & 5,54 \\
F2 & 4,90 & 5,53 & 5,66 & 5,70 & 5,83 \\
F3 & 4,99 & 5,03 & 5,87 & 5,93 & 6,04 \\
F4 & 5,26 & 5,46 & 5,90 & 5,99 & 6,12 \\
F5 & 5,33 & 5,97 & 6,22 & 6,26 & 6,31 \\
\hline
\end{tabular}

Nilai pH F1, F2, F3, F4, F5 masih termasuk ke dalam rentang, maka dapat disimpulkan bahwa formulasi tersebut aman digunakan pada kulit dan tidak akan timbul iritasi. F1 memiliki nilai $\mathrm{pH}$ yang lebih rendah dari pada formulasi lain karena F1 lebih banyak terdapat kefir susu sapi, kefir sendiri merupakan produk fermentasi yang menghasilkan asam laktat dari laktosa oleh mikroba seperti Lactococcus lactis,Lactobacillus acidophilus (Safitri dan Swarastuti., 2013)

\section{Uji Viskositas}

Didapatkan hasil dari triplo Uji Viskositas yang terdapat pada Tabel 4.

Tabel 4. Pengujian Viskositas

\begin{tabular}{crrrrr}
\hline & \multicolumn{5}{c}{ Waktu pengujian } \\
\cline { 2 - 6 } Formulasi & Hari ke-0 & Hari ke-7 & Hari ke-14 & Hari ke-21 & Hari ke-28 \\
& & & & & \\
\hline F1 & 3266 & 2300 & 2133 & 2966 & 2433 \\
F2 & 3700 & 2716 & 2716 & 3250 & 2466 \\
F3 & 2866 & 2650 & 2466 & 2466 & 2150 \\
F4 & 3800 & 3650 & 3650 & 3650 & 3933 \\
\hline
\end{tabular}

Viskositas merupakan karakteristik yang penting karena mempengaruhi pelepasan zat aktif dari sediaan, viskositas memiliki hubungan dengan kestabilan 
masker krim yang dibuat (Matrin, et al., 1993). Sampel F3 memiliki nilai viskositas yang paling kecil dibandingkan dengan formula lain yang merupakan formula paling stabil secara fisik. Dalam pengujian nilai viskositas mengalami perubahan selama penyimpanan, semakin kecil perubahan viskositas maka masker krim semakin stabil.

\section{Uji Iritasi}

Uji iritasi dilakukan secara klinik yaitu pada punggung tangan manusia, didapatkan hasil yang tertera pada Tabel 5 .

Tabel 5. Pengujian Iritasi

\begin{tabular}{cccccc}
\hline \multirow{2}{*}{ Responden } & \multicolumn{5}{c}{ Formulasi } \\
\cline { 2 - 6 } & F1 & F2 & F3 & F4 & F5 \\
\hline 1 & - & - & - & - & - \\
2 & - & - & - & - & - \\
3 & - & - & - & - & - \\
4 & - & - & - & - & - \\
5 & - & - & - & - & - \\
6 & - & - & - & - & - \\
7 & - & - & - & - & - \\
8 & - & - & - & - & - \\
9 & - & - & - & - & - \\
10 & - & - & - & - & - \\
\hline
\end{tabular}

Pengujian iritasi dilakukan pada sepuluh responden uji yang terdiri dari wanita berusia 20-50 tahun dipilih yang telah memenuhi kriteria inklusi dan tidak memenuhi kriteria ekslusi (Trihapsoro, 2003). Reaksi iritasi kulit positif ditandai dengan adanya reaksi kemerahan (eritema) dan edema pada daerah kulit yang diberi perlakuan (Irsan dkk., 2013). Dari 10 responden tidak menunjukan adanya reaksi kemerahan atau gatal pada punggung lengan. 


\section{Uji Tipe Krim}

Uji dilakukan agar dapat diketahui sedian masker krim termasuk tipe air dalam minyak atau minyak dalam air hasil pengujian terdapat di Tabel 6.

Tabel 6. Pengujian tipe krim

\begin{tabular}{ccc}
\hline Formulasi & M/A & A/M \\
\hline F1 & $\checkmark$ & \\
F2 & $\checkmark$ & \\
F3 & $\checkmark$ & \\
F4 & & $\checkmark$ \\
F5 & & $\checkmark$ \\
\hline
\end{tabular}

Penentuan tipe krim dilakukan karena pada umumnya untuk tujuan kosmetik lebih cocok krim bertipe minyak dalam air salah satunya karena mudah tercuci air sehingga mudah digunakan. Pada F1, F2, dan F3 termasuk kedalam tipe emulsi minyak dalam air.

\section{Uji Penghambatan Enzim Tirosinase}

Pengujian penghambatan enzim tirosinase menggunakan sampel F3 karena dari semua uji merupakan sediaan yang paling baik. Dari pengujian menggunakan alat ELISA reader didapatkan nilai absorbansi yang akan digunakan dalam penentuan nilai persentase inhibisi. Konsentrasi dari masing-masing sampel dan kontrol dapat menghambat setengah dari aktivitas tirosinase (IC50) ditentukan dengan cara membandingkan absorban dengan sampel dan tanpa penambahan sampel. Hasil regresi didapatkan dengan memplotkan konsentrasi dengan absorbansi. Persamaan regresi linear dari kontrol didapatkan :

$$
\mathrm{Y}=\mathrm{ax}+\mathrm{b} \longrightarrow \mathrm{Y}=18,432 \mathrm{x}+27,08
$$

Dari data \%Inhibisi dan konsentrasi kontrol dilakukan dibuat grafik yang dapat dilihat pada Gambar 3.

doi: http://dx.doi.org/10.23960/aec.v5.i1.2020.p42-52 


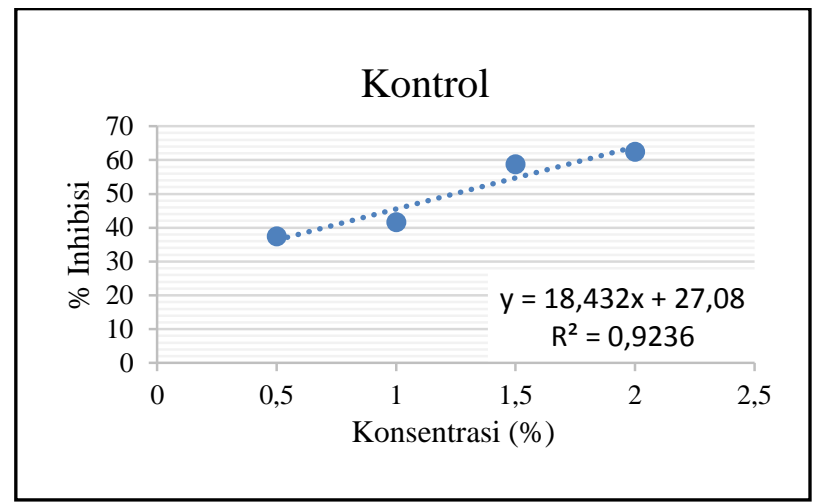

Gambar 3. Persen Inhibisi kontrol

Nilai inhibisi dari kontrol dengan perbedaan konsentrasi mengalami kenaikan yang signifikan. Nilai IC50 dari kontrol yaitu 1,24\%.

Berikut persamaan regresi linear dari sampel :

$$
\mathrm{Y}=\mathrm{ax}+\mathrm{b} \longrightarrow \mathrm{Y}=26,674 \mathrm{x}+43,02 \text {. }
$$

Dari persamaan linear dapat ditentukan nilai IC50. Nilai IC50 dari sampel yaitu $0,26 \%$. Besarnya nilai persen penghambat tirosinase sampel lebih kecil dibandingkan dengan kontrol yang mengandung asam kojat sehingga dapat disimpulkan bahwa sampel yang mengandung kefir susu sapi dan rumput laut memiliki aktivitas penghambatan tirosinase yang lebih besar dibandingkan dengan kontrol asam kojat pada konsentrasi yang sama.

\section{KESIMPULAN}

Formulasi maker pencerah wajah dari kefir susu sapi dengan penambahan rumput laut yang mempunyai kestabilan paling optimal yaitu pada formulasi 3 karena dari semua uji merupakan sediaan yang paling baik. Sampel F3 (IC50 sebesar 0,26\%) dapat menghambat kerja enzim tirosinase lebih baik dari pada kontrol asam kojat (IC50 sebesar 1.24\%) pada pembentukan melanin. 


\section{DAFTAR PUSTAKA}

Anggraeni. D. N, 2010. Uji stabilitas Fisik dan Aktivitas Inhibisi Tirosin terhadap krim Ekstrak Kulit Buah Manggis (Garcinia mangostana L.) yang dibuat dengan metode dingin dan panas.

Anindita. A. H, Af. S. Masluhiya., 2017. Formulasi Masker Alami Berbahan Dasar Rumput Laut Dan Cokelat Mengurangi Keriput Dan Bintik Noda Pada Kulit Wajah. Jurnal Care Vol .5, No.2.

Chen. M. J, Liu. J, Sheu. J, Lin. C and Chuang. C., 2017. Study on Skin Care Properties of Milk Kefir Whey.

Departemen Perindustrian. 2006. Roadmap Industri Susu. Direktorat Jenderal Industri Agro dan Kimia Departemen Perindustrian, Jakarta.

Grace, F.X., C. Darsika, K.V. Sowmya, K. Suganya, and S. Shanmuganathan. 2015. Preparation and Evaluation of Herbal Peel Off Face Mask. American Journal of PharmTech Research. (5): 33-336.

Liu, J. R., M. J. Chen and C. W. Lin. 2005. Antimutagenic and Antioxidant properties of milk kefir and soymilk kefir. J. Agr. Food Chem. 53:2467-2474.

Michael, Sidharta. B. br, Purwijantiningsih. L. M. E., 2014. POTENSI KEFIR SEBAGAI ANTI BAKTERI Propionibacterium acnes.

Rahmadi. P, Pangestuti. R And Salim. G., 2015. Potensi Rumput Laut Sebagai Bahan Dasr Kosmeseutikal.

Rumput Laut (Eucheuma Cottoni) Menjadi Serbuk Minuman Instan. Vol.8 No.2 ISSN 1693 9085 hal $101-109$.

Wahyuni, Lullung. A, Asriati. W. D., 2016. Formulasi Dan Peningkatan Mutu Masker Wajah Dari Biji Kakao Non Fermentasi Dengan Penambahan Rumput Laut..

doi: http://dx.doi.org/10.23960/aec.v5.i1.2020.p42-52

Anal.Environ.Chem. 